International Politics: Gary Zuk (Auburn)

Legislative Politics: Randall Strahan (Emory)

Political Theory: Steven Kautz (Emory)

Parties and Interest Groups: Steve Finkel (Virginia)
Public Law: Deborah Barrow (Auburn)

Public Policy and Administration: Keith Hamm (Rice)

Race and Ethnicity: William Boone (Clark-Atlanta)

Southern Politics: Harold Stanley (Rochester)
State and Local Politics: Joel Thompson (Appalachian State)

Public Opinion and Elections: Kathleen Knight (Houston) Urban Politics: Carol Pierannunzi (Kennesaw State)

Women and Politics: Laura Woliver (South Carolina)

\title{
Midwest Political Science Association News
}

\author{
John Pelissero, Executive Director, Midwest Political Science \\ Association
}

\section{Political Science Videos Available}

The Midwest Political Science Association (MPSA) began videotaping some of the important panels at the 1991 annual meeting and has the following tapes available for purchase:

\section{"The Interdisciplinary Foundations of Political Science"}

(1 hour, 24 minutes; \$20)

The theoretical and research foundations of political science that stem from work in other disciplines are discussed by four political scientists who have developed much of their own work from other social sciences. The program is moderated by Donald Stokes (Princeton) and includes Russell Hardin (Chicago), David O. Sears (UCLA), and John Sprague (Washington University, St. Louis). This program is the Plenary Session of the 1991 Midwest Political Science Association Annual Meeting.

\section{"The Dissertation:}

Getting Started, Getting Done"

(1 hour, 35 minutes; \$20)

A panel of experts on the dissertation process share ideas on beginning and finishing the research and writing of a dissertation in political science. The program is moderated by Robert H. Salisbury (Washington University, St. Louis) and includes Dianne Pinderhughes (Illinois), Kenneth J. Meier (Wisconsin-Milwaukee), and Steven Rosenstone (Michigan). The program is very useful for graduate students and fac- ulty advising dissertation students.

The tapes are available from: Midwest Political Science Association, Loyola University Chicago, $6525 \mathrm{~N}$. Sheridan Road, Chicago, IL 60626. Tapes are $\$ 20$ each or both may be purchased for $\$ 35$; check or purchase order accepted.

\section{New Books Published}

The Midwest Political Science Association sponsored a series of panels on the Future of Political Science at the 1989 meeting of the organization. Now the Northwestern University Press has published a four-volume collection, Political Science: Looking to the Future, edited by William Crotty (Northwestern) that grows out of this 1989 program. The volumes assess developments in subfields of political science that are important as the discipline enters the 1990s. The royalties from this series benefit the Midwest Political Science Association and are dedicated to a future series of books and conference programs. The volumes and their contents are:

\section{Volume I: The Theory and Practice} of Political Science

Table of Contents

1. "Setting the Stage," William Crotty

2. "The Making of a Discipline," Donald M. Freeman

3. "Pluralism and Progress in the Study of Politics," J. Donald Moon
4. "Whither Political Theory?," Terence Ball

5. "The Theory of Rational Action: What Is It? How Useful Is It for Political Science?," Kristen Renwick Monroe

6. "Analytic Theory and Methodology,' Paul E. Johnson and Philip A. Schrodt

7. "Gender Politics, Gendered Politics: The State of the Field," Virginia Sapiro

8. "Paradigms and Paradoxes: Political Science and African American Politics," Michael C. Dawson and Ernest J. Wilson III

Biographical Sketches of the Authors

Volume II: Comparative Politics, Policy and International Relations

Table of Contents

1. "Setting the Stage," William Crotty

2. "Comparative Politics of the Industrial Democracies: From the Golden Age to Island Hopping," Russell J. Dalton

3. "Paradigms and Sand Castles in the Comparative Politics of Developing Areas," Barbara Geddes

4. "Where Have We Been and Where Are We Going?: Analyzing the Politics of Socialism in the 1990s," Ellen Comisso

5. "Foreign Policy Analysis: Renaissance, Routine or Rubbish?," Deborah J. Gerner

6. "The Study of War and Peace: Quo Vadis?," Jacek Kugler

7. "Political Economy Within Nations," William R. Keech, Robert Bates and Peter Lange 
8. "Public Policy: Toward Better Theories of the Policy Process," Paul Sabatier

Biographical Sketches of the Authors

\section{Volume III: Political Behavior}

Table of Contents

1. "Setting the Stage," William Crotty

2. "Political Attitudes: A Historical Artifact or a Concept Continuing Importance in Political Science?," Norman Luttbeg

3. "The Study of Political Participation: Past, Present, Future," M. Margaret Conway

4. "The Study of Electoral Behavior," Jack Dennis

5. "Media and Politics," Doris A. Graber

6. "Political Socialization: Where's the Politics?," Pamela Johnston Conover

7. "Political Psychology: Where Have We Been? Where Are We Going?," Betty Glad
8. "Toward Cultural Theories of American Political Behavior, Religion, Ethnicity and Race, and Class Outlook,"' David Leege, Joel A. Lieske and Kenneth D. Wald

Biographical Sketches of the Authors

\section{Volume IV: American Institutions}

Table of Contents

1. "Setting the Stage," William Crotty

2. "Legislative Research: Mirror of a Discipline," Roger H. Davidson

3. "What Do We Know and How Do We Know It? Research on the Presidency," Paul J. Quirk

4. "Judicial Politics," Elliot E. Slotnick

5. "Interest Groups: A Subfield in the Search of an Identity," Allan J. Cigler

6. "Political Parties: Issues and Trends," William Crotty

7. "Federalism and Intergovernmental Relations: The Centralization v. Decentralization Debate Continues," Susan A. MacManus

8. "The Study of State and Local Politics: A Preliminary Exploration of Its Contributions to Empirical Political Theory," Ronald E. Weber

9. "Urban Politics and Political Science," Kenneth R. Mladenka and Bryan Jones

Biographical Sketches of Authors

The books are available in paperback or cloth editions from: Northwestern University Press, 625 Colfax Street, Evanston, IL 60201. Cloth prices: $\$ 47.95$ (Volumes 1, 3); $\$ 57.95$ (Volumes 2, 4); Paperback prices: $\$ 15.95$ (Volumes 1,3$) ; \$ 18.95$ (Volumes 2, 4). 